\title{
The Reaction of Bank Lending to Monetary Policy in Brazil $^{*}$
}

\author{
Tony Takeda** \\ Fabiana Rocha ${ }^{* * *}$ \\ Márcio I. Nakane ${ }^{* * * *}$
}

Summary: 1. Introduction; 2. Monetary policy indicators; 3 . The model; 4. Variable descriptions; 5. Estimation results; 6. Conclusions.

Keywords: monetary policy transmission; reserve requirements; bank lending channel.

JEL codes: E44; E52.

This paper evaluates the relevance of the "bank lending channel" of monetary policy transmission in Brazil. Disaggregated monthly data of the Brazilian banks balance sheets from December 1994 to December 2001 are analyzed. In addition to the short-term interest rate, we consider the effects of another monetary policy instrument frequently used in Brazil, represented by reserve requirements on overall banks deposits - demand, savings, and time deposits. Dynamic panel data techniques are employed. Our results suggest that the impact of reserve requirements is relevant and stronger for larger banks loans. This finding results from the progressive reserve rates required from banks, which affect to a greater extent banks with larger deposit volumes.

Este artigo avalia o canal de empréstimos bancários na transmissão da política monetária. A análise foca os dados mensais desagregados do balanço patrimonial dos bancos comerciais brasileiros de dezembro de 1994 a dezembro de 2001. Em adição à taxa básica

\footnotetext{
* This paper was received in Sep. 2003 and approved in Aug. 2004. The views expressed here are those of the authors and do not reflect those of the Central Bank of Brazil or its members. The authors thank, without implicating, the comments and suggestions made by an anonymous referee, Nelson Carvalheiro, Naércio Aquino Menezes Filho, Siegfried Bender, Marcos Bonomo, Angélica María Arosemena, Eduardo Fernandes, Arnildo da Silva Correa, Pedro Fachada, and seminar participants at Central Bank of Brazil, CEMLA 2003 Annual Meeting, ANPEC 2003 Annual Meeting, and EESP/FGV. The first author received financial support from the Graduate Studies Program of the Central Bank of Brazil.

${ }^{* *}$ Research Department, Central Bank of Brazil.

${ }^{* * *}$ Economics Department, São Paulo University.

${ }^{* * * *}$ Research Department, Central Bank of Brazil. Economics Department, São Paulo University.
} 
de juros de curto prazo, este estudo considera também os efeitos de um outro instrumento de política monetária usado freqüentemente no Brasil, representado pelos recolhimentos compulsórios sobre os depósitos à vista, de poupança e a prazo. A partir de técnicas de análise de dados em painel dinâmico, os resultados dos testes sugerem que o impacto dos compulsórios é relevante e é mais forte sobre os empréstimos dos grandes bancos, conclusão que decorre de recolhimentos compulsórios de caráter progressivo, que afetam mais fortemente os bancos com maiores volumes de depósitos.

\section{Introduction}

Between 1995 and 2001, total credit in Brazil fell from 35\% to 26\% of GDP. Even disregarding such a reduction, the credit-to-GDP ratio in Brazil has been historically very low when compared to other emergent economies.

Such low credit-to-GDP ratio has been mentioned in the literature as a possible reason to ignore a potential credit channel in the monetary policy transmission mechanism for Brazil (Bogdanski et al., 2000). However, this topic has continued to receive great attention from researchers and policy-makers. Souza Sobrinho and Nakane (2002) assessed the empirical relevance of the credit channel by studying aggregate credit data for the October 1996 to December 2001 period, concluding that bank credit works as a monetary transmission channel in Brazil. By contrast, Graminho and Bonomo (2002), following Kashyap and Stein (2000)'s methodology, make use of disaggregated banking credit data in the July 1994 to December 2001 period to conclude that rises in the short-term interest rate relax banks' balance sheets liquidity constraints. The authors attribute such result to the positive link between interest rate variations and bank profits. Based on such evidence, the authors conclude that the credit channel does not operate in Brazil.

This paper aims at revisiting the empirical evidence on the bank lending channel of monetary transmission in Brazil. We analyse banks' balance sheet monthly data for the period from December 1994 to December 2001. For industrialized countries, the monetary policy instrument usually considered in empirical studies is a short-term interest rate under the central bank control. This is also the indicator used by Graminho and Bonomo (2002). We argue that the short-term interest rate only partially captures the monetary stance in Brazil. When we consider a broader indicator of monetary policy that encompass all the required reserves on different types of bank deposits (demand, savings, and time deposits), we argue that there is evidence for a transmission mechanism working through bank lending. 
This paper is related to the empirical literature on the relevance of the credit channel in the monetary policy transmission mechanism (see Bernanke and Gertler (1995) for a survey). In particular, it is linked to what the literature terms the bank lending channel as contrasted to the broad credit channel (Kashyap and Stein, 1994, Oliner and Rudebusch, 1996). According to the latter, all sources of external financing work as imperfect substitutes for the firms' internal funding. The bank lending channel is a particular case of the broad credit channel due to its emphasis on just one source of external financing (namely, the supply of bank loans) in the monetary policy transmission. Most of the early empirical research on the bank lending channel made use of aggregate time-series data. ${ }^{1}$ However, the use of aggregate data is far from ideal due to the difficulty of disentangling demand and supply effects. Since the seminal work of Kashyap and Stein (2000), the use of bank-level data has been preferred in the literature to better deal with the identification problem. ${ }^{2}$ The main contribution of our paper to this growing literature is the incorporation of the role of reserve requirements as an additional policy instrument in the bank lending channel.

The paper is structured as follows. Section 2 makes the argument in favor of a broader monetary policy indicator for Brazil. Section 3 presents the basic model used, followed by the discussion of data issues in section 4. Section 5 shows and discusses the empirical results. The final section concludes the paper.

\section{Monetary Policy Indicators}

The usual monetary policy instrument found in the literature about the bank lending channel of monetary transmission is a short-term interest rate under the central bank's control. The short-term interest rate used in this paper is the overnight selic interest rate, set by the Monetary Policy Committee (Copom) in its monthly meetings.

However, another important monetary policy instrument in Brazil is the required reserve ratio on demand deposits. For instance, when the stabilization Real plan was launched in July 1994, such ratio was set at $100 \%$ at the margin. After several reductions, it reached $45 \%$ by December 2001. In addition, reserve requirements were also set for time deposits, savings deposits and other bank lia-

\footnotetext{
${ }^{1}$ See, among others, Bernanke and Blinder (1992), Gertler and Gilchrist (1993), and Kashyap et al. (1993). See Souza Sobrinho and Nakane (2002) for an application to Brazil.

${ }^{2}$ In addition to Kashyap and Stein (2000), see also Brissimis et al. (2003), Ehrmann et al. (2003), Farinha and Robalo Marques (2003), Gambacorta (2003), Hernando and Martínez-Pagés (2003), Kaufmann (2003), and Worms (2003).
} 
bilities such as judicial deposits and mutual funds. In a short period immediately after the Real plan reserves were required even for bank lending operations. The rates on such required reserves are frequently changed by the Central Bank for liquidity control purposes. Table 1 summarises the main changes in rates on demand, time and saving deposits for the 1994-2001 period. Remuneration criteria on reserve requirements have also been frequently changed by the Central Bank for policy purposes. ${ }^{3}$ Thus, it seems paramount to consider the effects of such required reserves on the variations of bank credit in the country.

Table 1

Reserve requirement rates (1994-2001)

\begin{tabular}{lccc}
\hline Period & $\begin{array}{c}\text { \% on Demand } \\
\text { Deposits }\end{array}$ & $\begin{array}{c}\text { \% on Time } \\
\text { Deposits }\end{array}$ & $\begin{array}{c}\text { \% on Saving } \\
\text { Deposits }\end{array}$ \\
\hline Before Real Plan & 40 & 0 & 15 \\
Jul/94 & 100 & 20 & 20 \\
Aug/94 & 100 & 30 & 30 \\
Dec/94 & 90 & 27 & 30 \\
Apr/95 & 90 & 30 & 30 \\
Jul/95 & 83 & 30 & 30 \\
Aug/95 & 83 & 20 & 15 \\
Aug/96 & 82 & 20 & 15 \\
Sep/96 & 81 & 20 & 15 \\
Oct/96 & 80 & 20 & 15 \\
Nov/96 & 79 & 20 & 15 \\
Dec/96 & 78 & 20 & 15 \\
Jan/97 & 75 & 30 & 15 \\
Mar/99 & 75 & 25 & 15 \\
May/99 & 75 & 20 & 15 \\
Jul/99 & 75 & 10 & 15 \\
Sep/99 & 75 & 0 & 15 \\
Oct/99 & 65 & 0 & 15 \\
Mar/00 & 55 & 0 & 15 \\
Jun/00 & 45 & 10 & 15 \\
Sep/2001 & 45 & & 15 \\
\hline Source: Central Bank of Brazil & & \\
& & & \\
\hline
\end{tabular}

\footnotetext{
${ }^{3}$ For more details on the various required reserves in effect during the first months of the Real plan, see Melo and Teles (1998). For the changes in the required reserves rates in the last years, see Banco Central do Brasil (2000 and 2001, table: Medidas Propostas, Adotadas e em Andamento).
} 
Figure 1 shows the evolution of the effective reserve requirement ratios on demand deposits, and on overall deposits. ${ }^{4}$ One can see that the reserve requirement rate on demand deposits shows a clear decreasing trend in the period, with discrete jumps. A different picture emerges from the observation of the reserve requirement rate on overall deposits. This indicator shows greater variability, with periods of tightning being generally associated to periods of turbulence in the financial markets.

Figure 1

Reserve requirement rates (1995-2001)
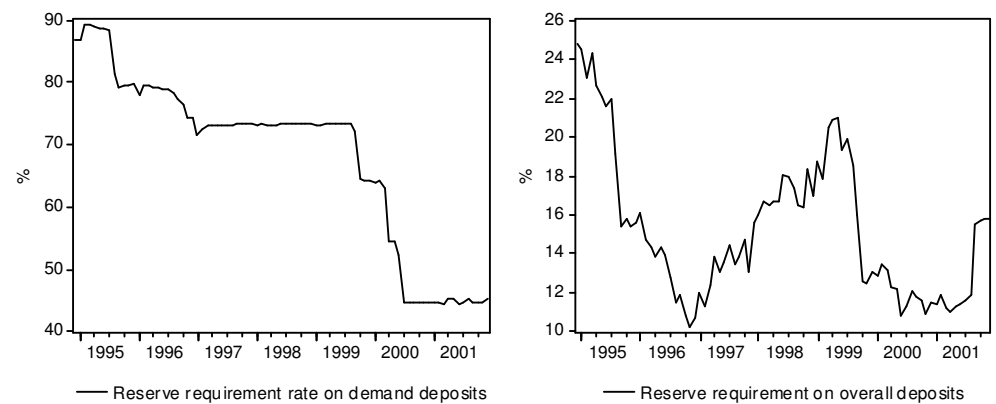

The consideration of reserve requirement rates as additional policy instruments has one great advantage over the short-term interest rate. The literature on the bank lending channel has called the attention for a possible identification problem related to the direct impact of the coefficient on interest rate on bank loan equations; rather than capturing the effect on the supply of loans, which is the interpretation favored by the bank lending channel advocates, one could also interpret such coefficient as reflecting a loan demand effect. ${ }^{5}$ But, since reserve requirements are levied solely on banks, the identification problem is much less acute for this instrument. In other terms, even the direct coefficient associated to this instrument can safely be interpreted as capturing a loan supply effect.

\footnotetext{
${ }^{4}$ The reserve requirement ratio on overall deposits was calculated from the sum of all required reserves (in cash, remunerated and non-remunerated, and in securities) over the sum of all deposits of all commercial banks in the sample.

${ }^{5}$ Kashyap and Stein (2000) suggest the inclusion of interaction terms between the policy instrument and bank individual characteristics to identify the bank lending channel. This strategy will also be followed in our paper.
} 
Figure 2

Exchange rate, selic interest rate and inflation rate (1995-2001)
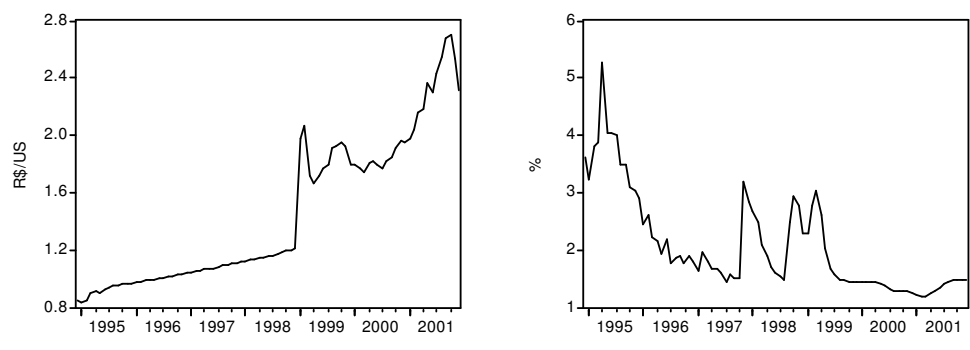

- Exchange rate (end of month bid quotation)
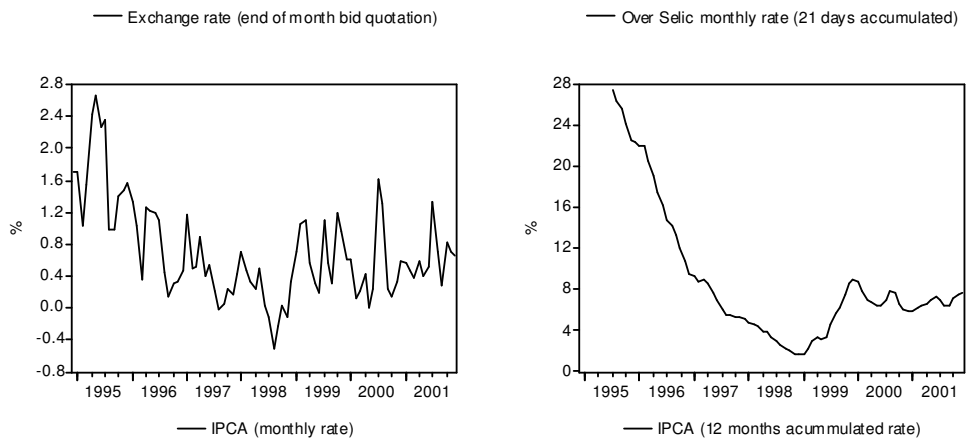

Figure 2 shows the evolution of the $\mathrm{R} \$ / \mathrm{US} \$$ exchange rate, of the overnight selic interest rate, of the inflation rate as measured by the monthly variation of the IBGE's consumer price index IPCA, and of the 12-month accumulated inflation rate. In the period analysed, Brazil was under two different monetary and exchange rate policy regimes: a crawling peg exchange rate, from March 1995 to December 1998; and an inflation targeting regime with floating exchange rate, from July 1999 onwards. One can notice that during both regimes, the selic interest rate was a widely used policy instrument. During the first period, discrete hikes in the selic rate contributed to sustain the exchange rate regime in periods of foreign financial market turmoils (the Mexican crisis in March 1995, the Southeast Asia crisis in October 1997, and the Russian crisis in August 1998). The jump in the selic rate in March 1999 was primarily aimed at reverting negative inflationary expectations following the flotation of the exchange rate in January 1999. After the adoption of the inflation targeting regime in July 1999, the volatility of the selic rate has greatly reduced whereas the exchange rate volatility has increased. 


\section{The Model}

The empirical test of the lending channel in Brazil takes Ehrmann et al. (2003)'s model as a benchmark. Their model is adapted to the case where there is more than one policy instrument.

The market for bank deposits is described by an equilibrium relationship, where deposits $(D)$ are taken to be equal to money $(M)$, with both being functions of the interest rate $i$ set by the monetary authority, as follows:

$$
M=D=-\psi i+\chi, \text { where } \chi \text { is a constant }
$$

Bank $i$ faces a loan demand $\left(L_{i}^{d}\right)$ that depends on economic activity $(y)$, on the inflation rate $(i n f l)$, and on the loan nominal interest rate $\left(i_{L}\right)$ :

$$
L_{i}^{d}=\phi_{1} y+\phi_{2} \text { infl- } \phi_{3} i_{L}
$$

Loan demand is supposed to be positively related to economic activity, and negatively related to the loan nominal interest rate. There is no a priori sign for the coefficient on inflation. Theoretical models suggest that any sign is possible. Cukierman and Hercowitz (1989) present a model where loan demand is positively related to inflation. In their model, firms make use of both money and bank loans to pay for working capital. High inflation penalizes money holdings by firms and makes bank loans more attractive. By contrast, De Gregorio and Sturzenegger (1997) develop a model where the demand for bank credit by firms reduces with inflation because, in their model, higher inflation is related to lower productivity levels, which, in turn, reduces the demand for labor. Huybens and Smith (1999) show that both outcomes are actually possible depending on the nature of the steady-state equilibrium in the economy. ${ }^{6}$

The loan supply by bank $i\left(L_{i}^{s}\right)$ is a function of the available amount of money (or deposits), of the loan nominal interest rate, and of the monetary policy instrument(s) $(z)$, where the instrument can either be the interest rate set by the Central Bank or the reserve requirements rate on deposits $(\sigma)$ or both. The direct impact of the policy interest rate represents the opportunity costs for banks when banks make use of the interbank market as a liquidity source. ${ }^{7}$ Thus, loan supply is given by:

${ }^{6}$ The available empirical evidence also seems not to support any strong link between inflation and bank credit. Ehrmann et al. (2003) report negative impacts for France and Spain, positive effects for Germany, and non-significant coefficients for Italy.

${ }^{7}$ Souza Sobrinho and Nakane (2002) provide empirical evidence from aggregate data for the reaction of bank interest rates to monetary policy in Brazil. 


$$
L_{i}^{s}=\mu_{i} D_{i}+\phi_{4} i_{L}-\phi_{5} z
$$

In addition, it is assumed that not all banks are equally dependent on deposits. In particular, the model considers that the impact of a change in deposits is smaller the lower the bank characteristic related to size or liquidity $\left(x_{i}\right)$ is: ${ }^{8}$

$$
\mu_{i}=\mu_{0}-\mu_{1} x_{i}
$$

The equilibrium condition in the lending market plus equations (1) to (4) result in the following reduced form for the model:

$$
L_{i}=\frac{\phi_{1} \phi_{4} y+\phi_{2} \phi_{4} \text { infl- }-\left(\phi_{5}+\mu_{0} \psi\right) \phi_{3} z+\mu_{1} \psi \phi_{3} z x_{i}+\mu_{0} \phi_{3} \chi-\mu_{1} \phi_{3} \chi x_{i}}{\phi_{3}+\phi_{4}}
$$

Expression (5) can be more concisely expressed as:

$$
L_{i}=a y+b \text { infl- } c_{0} z+c_{1} z x_{i}-d x_{i}+\text { constant }
$$

The coefficient $c_{1}=\frac{\mu_{1} \psi \phi_{3}}{\phi_{3}+\phi_{4}}$ relates the reaction of bank $i$ 's loans to the monetary policy interacting with its characteristic. Under the model assumptions, a significant $c_{1}$ coefficient implies that the monetary policy affects the supply of loans. An implicit identifying assumption is that the interest rate loan demand elasticity does not depend on the bank characteristic $\left(x_{i}\right)$, i.e. that the coefficient $\phi_{3}$ is the same for all banks.

The assumption of a homogeneous reaction of the loan demand is crucial for the identification of the monetary policy effects on loan supply. This assumption rules out the cases where, for example, small or large bank customers are more sensitive to interest rate changes. Such assumption seems reasonable for Brazil in view of the fact that bank loans are the main source of finance in Brazil, with few substitutes available, even for large firms. ${ }^{9}$

In addition, the empirical model allows for asymmetric responses of bank loans to changes in the economic activity and in the inflation rate by interacting such

\footnotetext{
${ }^{8}$ Another bank characteristic usually investigated in the literature is its degree of capitalization (net worth to assets). However, due to the accounting legislation in Brazil, commercial banks have to report full income statements only twice a year, in June and in December. Since such statements are required to calculate the bank's net worth coupled with the fact that the empirical estimates use monthly observations, we decided not to use banks' capitalization ratios.

${ }^{9}$ In a similar study, Worms (2003) introduces a proxy for the loan demand, which allows him to model differences in loan demand across banks.
} 
variables with bank characteristics. ${ }^{10}$ The model also allows for dynamic adjustments and the estimation is done for the variables in first-differences due to non-stationarities. ${ }^{11}$ The regression model is specified as follows: ${ }^{12}$

$$
\begin{aligned}
\Delta \log \left(L_{i t}\right) & =\sum_{j=1}^{m} a_{j} \Delta \log \left(L_{i t-j}\right)+\sum_{j=0}^{m} b_{j} \Delta r_{t-j}+\sum_{j=0}^{m} c_{j} \Delta \log \left(y_{t-j}\right) \\
& +\sum_{j=0}^{m} d_{j} \Delta i n f l_{t-j}+e x_{i t-1}+\sum_{j=0}^{m} f_{1 j} x_{i t-1} \Delta r_{t-j} \\
& +\sum_{j=0}^{m} f_{2 j} x_{i t-1} \Delta \log \left(y_{t-j}\right)+\sum_{j=0}^{m} f_{3 j} x_{i t-1} \Delta i n f l_{t-j}+\epsilon_{i t}
\end{aligned}
$$

with $i=1, \ldots, N$ and $t=1, \ldots, T_{i}$. $N$ denotes the number of banks and $m$ is the number of lags. $L_{i t}$ is the amount of loans by bank $i$ in period $t, \Delta r_{t}$ represents the first difference of the short-term nominal interest rate, $\Delta \log \left(y_{t}\right)$ is the growth rate of the economic activity indicator, and $\Delta i n f l_{t}$ is the first difference of the inflation rate. The individual bank characteristics are denoted by $x_{i t}$.

The asymmetric effects of monetary policy are captured by significant coefficients for the interaction terms. The literature has found that smaller (Kashyap and Stein, 1995, 2000), less liquid (Kashyap and Stein, 2000, Ehrmann et al., 2003), or less capitalized (Peek and Rosengren, 1995) banks react more to changes in monetary policy. These results imply positive coefficients for the interaction terms.

A better understanding about the sign of the interaction term coefficient can be gauged by examining the relevant terms in equation (6), reproduced below:

$$
\ln \left(L_{i}\right)=\ldots+b \ln (r)+c x_{i} \ln (r)+\ldots
$$

where $L_{i}$ is the amount of loans by bank $i, r$ is the short-term interest rate controlled by the Central Bank, $b$ is the coefficient on the direct impact of monetary policy, $x_{i}$ is the characteristic $x$ for bank $i$, and $c$ is the coefficient of the interaction between the characteristic $x$ for bank $i$ and $\ln (r)$.

\footnotetext{
${ }^{10}$ In other terms, different values for $\phi_{1}$ and for $\phi_{2}$ among banks with different sizes, liquidity or any other characteristic $\left(x_{i}\right)$ are allowed.

${ }^{11}$ The dynamic specification accounts for the fact that banks react to policy changes by adjusting the concession of new loans.

${ }^{12}$ When the monetary policy indicator is the reserve requirements on deposits $(\sigma), \Delta r$ is replaced by $\Delta \sigma$ in equation (7).
} 
It seems reasonable to suppose that $\frac{\partial \ln \left(L_{i}\right)}{\partial \ln (r)}=b+c x_{i}<0$, implying that the amount of bank $i$ loans reduces with increases in the interest rate. If the $x_{i}$ bank characteristic represents liquidity, size or capitalization, then one expects to find $b<0$ and $c>0$.

Suppose, for example, that $x_{i}$ represents the bank $i$ liquidity position. A positive $c$ coefficient implies that more liquid banks respond less to a monetary policy contraction represented by an increase in the interest rate. ${ }^{13}$ Figure 3 illustrates this situation.

Figure 3

Sign of the interaction coefficient between bank characteristic and monetary policy instrument

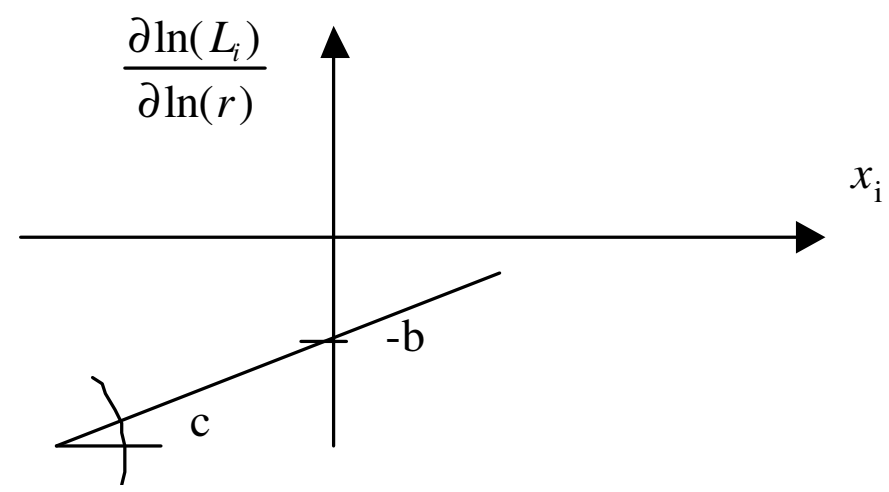

\section{Variable Descriptions}

The dependent variable in this study is represented by freely allocated bank credit. Such loans refer to the portion of total bank loans that are granted at market interest rates. These are the loans that are, presumably, more sensitive to changes in monetary policy. ${ }^{14}$ Freely allocated credit excludes agricultural and housing loans from the credit outstanding, because these two categories are allo-

\footnotetext{
${ }^{13}$ Notice that the same observations about the sign of the $c$ coefficient remain valid when one takes the reserve requirement rate as the monetary policy instrument.

${ }^{14}$ Nakane and Takeda (2002) estimate vector auto-regressions (VARs) to study the impact of monetary policy on bank balance sheets using aggregate data for Brazilian banks over the period Dec/1994 to Aug/2002. The authors found that overall bank credit do not respond to shocks in the monetary policy instruments (selic interest rate and reserve requirement rate on demand deposits). However, they found that freely allocated bank loans shows a negative and significant response to positive shocks in the selic interest rate.
} 
cated according to legally binding directed-lending requirements at governmentset interest rates. ${ }^{15}$ Figure 4 pictures the evolution of freely allocated credit (in constant value, left picture) as well as the share of both total credit and freely allocated credit on total banks assets (right picture). There is an upward trend in freely allocated credit both in absolute terms as well as a share of total loans, particularly since the end of 1999 .

Figure 4

Freely allocated bank loans, and total bank loans
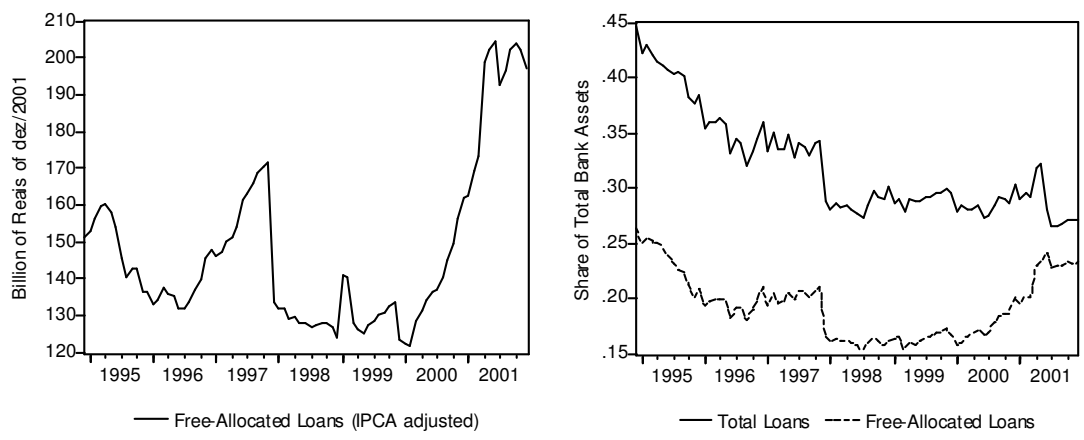

As discussed in section 2, two policy instruments are considered in the paper, namely a short-term interest rate and reserve requirements on deposits. The shortterm interest rate is given by the selic overnight interest rate where the daily rates were capitalized and adjusted for a fixed 21-day period. ${ }^{16}$

Two measures of reserve requirement rates are tested, the effective reserve requirement rate on demand deposits and the effective reserve requirement on overall deposits, which is the sum of required reserves (in cash and in securities) over total demand, time and saving deposits (henceforth, "overall deposits").

Economic activity is proxied by the monthly industrial output as calculated by the Brazilian Institute of Geography and Statistics (IBGE). Inflation rate is measured by the monthly variation of the consumer price index IPCA calculated by IBGE, which is also the official inflation targeting indicator (since 1999).

\footnotetext{
${ }^{15}$ For the same reason, we also exclude loans from BNDES, a state-owned development bank. BNDES grants both earmarked loans and loans from a network of accredited financial institutions.

${ }^{16}$ The Central Bank Monetary Policy Committee (Copom) establishes the target for the annual selic interest rate. As an operational procedure, the Central Bank aims at targeting the daily selic rate given by $(1+\text { Annual selic rate })^{1 / 252}$, considering therefore a year with 252 days in 12 months, or a month with 21 days.
} 
Two bank characteristics are considered in the paper, namely bank size (Size) and liquidity (XLiq), defined as follows:

$$
\begin{gathered}
\text { Size }_{i t}=\log A_{i t}-\frac{1}{N_{t}} \sum_{i} \log A_{i t} \\
X L i q_{i t}=\frac{L i q_{i t}}{A_{i t}}-\frac{1}{T} \sum_{t}\left(\frac{1}{N} \sum_{i} \frac{L i q_{i t}}{A_{i t}}\right)
\end{gathered}
$$

Bank size is measured by the logarithm of total bank assets, $A_{i t}$ where total bank assets are the sum of current and non-current bank assets. The liquidity index is defined as the ratio of liquid assets $\left(L i q_{i t}\right)$ to total bank assets. Liquid assets are the sum of free securities and bonds and inter-bank operations (aplicações interfinanceiras de liquidez), excluding securities sold and not yet settled (revendas a liquidar).

Both bank characteristics are normalized with respect to the mean, calculated over the total number of banks in the sample (247 banks). Thus, the sample mean on the interaction term $x_{i t-1} \Delta r_{t-j}$ in equation (7) is zero. The $c_{j}$ coefficients in this equation can therefore be directly interpreted as measuring the overall impact of monetary policy on bank loans for the average bank in the sample. With regard to bank size, the normalization was done with respect to each time period. This procedure removes undesirable nominal trends in this variable.

Some outliers were removed from the sample in the econometric estimations. The outliers were identified as the values below (above) the $5^{\text {th }}\left(95^{\text {th }}\right)$ percentile for the distribution of the first difference of free allocated bank loans, of total bank assets, and of total bank deposits. This procedure was adopted due to the strong adjustment in the banking industry following the launching of the stabilization plan (Plano Real) in July 1994. The cut-off levels used in the paper smoothes the effects of adjustments in bank portfolios due to bankruptcies, mergers and acquisitions, as well as the privatizations that occurred in the period.

Tables 2 and 3 provide a concise picture of the Brazilian banking system by partitioning all the commercial banks operating in the country by December 2001 according to quartiles, defined over the distribution of free allocated bank loans to total assets. ${ }^{17}$

\footnotetext{
${ }^{17}$ The overall picture for other time periods is similar. In tables 2 and 3 the bank characteristics are not adjusted to the overall sample mean. Outliers are also not excluded.
} 
Table 2

Bank assets - distribution according to free-allocated loans to total assets

(December 2001)

\begin{tabular}{lccccc}
\hline & \multicolumn{3}{c}{$\begin{array}{c}\text { Distribution by free allocated } \\
\text { loans to total assets (1) }\end{array}$} & \multirow{2}{*}{ Total } \\
\cline { 2 - 5 } & Up to 25th & $\begin{array}{c}25 \text { th to } \\
50 \text { th }\end{array}$ & $\begin{array}{c}50 \text { th to } \\
75 \text { th }\end{array}$ & $\begin{array}{c}\text { Above } \\
75 \text { th }\end{array}$ \\
\hline Number of banks & 45 & 44 & 45 & 45 & 179 \\
Mean of assets (in million of $\mathrm{R} \$$ ) & 1,156 & 9,599 & 7,559 & 685 & 4,723 \\
Median of assets (in million of R $\$$ ) & 272 & 2,057 & 1,245 & 183 & 661 \\
\hline (1) Position of the five largest banks by assets (centile in square brackets): & \\
2nd quartile: Caixa Econômica Federal (CEF) [25th], Banco do Brasil (BB) [39th]. \\
3rd quartile: Banco Itaú [53rd], Bradesco [61st], Unibanco [66th].
\end{tabular}

Table 3

Liquidity, reserve requirements and selected indicators - banks classified by free allocated loans to total assets (December 2001)

\begin{tabular}{|c|c|c|c|c|c|c|c|c|c|}
\hline & \multicolumn{8}{|c|}{$\begin{array}{c}\text { Distribution by free allocated } \\
\text { loans to total assets }\end{array}$} & \multirow{3}{*}{$\begin{array}{c}\text { Share } \\
\text { of total } \\
\text { Assets } \\
(\%)\end{array}$} \\
\hline & \multicolumn{2}{|c|}{ Up to 25 th } & \multicolumn{2}{|c|}{25 th to 50 th } & \multicolumn{2}{|c|}{50 th to 75 th } & \multicolumn{2}{|c|}{ Above 75 th } & \\
\hline & $(1)$ & $(2)$ & $(1)$ & $(2)$ & $(1)$ & $(2)$ & $(1)$ & $(2)$ & \\
\hline Assets & 6.2 & 100 & 50.0 & 100 & 40.2 & 100 & 3.6 & 100 & 100 \\
\hline Free allocated loans & 0.5 & 1.7 & 29.2 & 13.7 & 58.1 & 33.7 & 12.3 & 78.5 & 23.4 \\
\hline Time + Interbank deposits & 4.5 & 15.4 & 46.5 & 19.8 & 38.3 & 20.2 & 10.7 & 62.5 & 21.2 \\
\hline Securities and derivatives & 9.8 & 75.0 & 54.1 & 50.8 & 34.9 & 40.6 & 1.2 & 15.9 & 46.9 \\
\hline Liquidity & 10.4 & 36.6 & 59.2 & 25.6 & 29.0 & 15.5 & 1.4 & 8.5 & 21.6 \\
\hline Reserve requirements & 1.5 & 1.6 & 60.3 & 8.2 & 36.6 & 6.2 & 1.6 & 3.0 & 6.8 \\
\hline Net worth & 16.1 & 30.9 & 33.7 & 8.0 & 45.2 & 13.3 & 5.1 & 16.4 & 11.8 \\
\hline
\end{tabular}

(1) share on total banking system (\%)

(2) share on group assets, within each quartile (\%)

The following comments can be made after observing tables 2 and 3 :

- The banks included above the 75th percentile of the distribution, which characterize the group of banks that lend more, are relatively small. These banks accounted only for $3.6 \%$ of total bank assets in December 2001, with assets averaging $\mathrm{R} \$ 685$ million, the smallest average of the four groups. Free allocated loans accounted for $78.5 \%$ of their total assets and, despite their small size, their loans accounted for $12.3 \%$ of the total loans by the banking sector, a share 3.4 times larger than their share of total assets;

- This group of banks presented a liquidity index of $8.5 \%$ in December 2001, the smallest of the four groups. This feature may indicate that liquidity constraint is not a significant factor in the determination of the response of 
loan supply to monetary policy changes, a hypothesis to be tested in the next section;

- On the liability side, the main sources of funds for the group of banks that lend more are time and interbank deposits. These two categories of deposits reached $62.5 \%$ of the group's total assets, the largest of the four groups. Within interbank deposits, the largest share comes from banks that do not belong to the same financial conglomerate (not shown in the tables). This fact may indicate that this group of banks may not find very hard to raise funds even though they are small banks;

- There is another group of relatively small banks, which is the group of banks that belong to the first quartile, i.e. a group of banks with low lending levels. The important feature of this group of banks is their large holdings of securities and derivatives, which accounted for $75 \%$ of the group's total assets. Due to this fact, their liquidity index is the largest among the four groups;

- Large banks are distributed in the two intermediary quartiles, representing average levels of lending. An important characteristic of this group of banks is the heavier burden represented by reserve requirements. Reserve requirements present a progressive rate mechanism due to some deductions and exemptions for small banks.

\section{Estimation Results}

The presence of the lagged dependent variable in the set of regressors required the estimation of a dynamic panel data. We used the GMM technique due to Arellano and Bond (1991). The instruments for the lagged dependent variable are their own lagged values in levels with a one-lag window. The other explanatory variables are taken to be exogenous. The selected equations refer to those whose over identifying restrictions are not rejected by the Sargan test (in the second step estimation) and also to those that reject the first-order serial correlation test (both in the first and in the second step estimations).

The unrestricted model has four lags of all terms in equation (7) that admit lagged values. Heteroscedastic robust standard errors are calculated for inference purposes. Inference is always based on the first step estimations, following Arellano and Bond (1991)'s recommendation. Non-significant coefficients are progressively excluded from the model. Reported results refer to the sum of the significant 
coefficients. All regressions were estimated with the variables in first-differences since they are all non-stationary in levels.

We present two sets of results. Table 4 shows the results when the policy instruments are the selic interest rate (selic) and the reserve requirement rate on demand deposits (resdem). Table 5 shows the results when the policy instruments are the selic interest rate and the reserve requirement rate on overall deposits (resdep).

In table 4 , the direct impact of changes in the short-term interest rate is negative and significant. On the other hand, there is no evidence that reserve requirements on demand deposits have a direct impact on bank loans and therefore, at least for the average bank, one can reject the hypothesis that the banking lending channel of monetary policy transmission works through this policy instrument. The coefficient related to economic activity is positive (as expected) while the coefficient for inflation is negative. Both coefficients are significant.

Table 4

Impact on free-allocated bank loans - policy instruments: selic interest rate (selic) and reserve requirement rate on demand deposits (resdem)

\begin{tabular}{|c|c|c|c|}
\hline \multicolumn{2}{|c|}{ Variables } & Sum of estimated & Robust \\
\hline \multirow{12}{*}{ in $1^{\text {st }}$ differences } & $\log (\mathrm{L})$ & $0.8907^{* * *}$ & 0.0715 \\
\hline & Selic & $-0.0165^{* * *}$ & 0.0038 \\
\hline & $\log (y)$ & $0.0484^{*}$ & 0.0249 \\
\hline & Infl & $-0.0166^{* * *}$ & 0.0037 \\
\hline & XLiq1 & $0.0174^{* * *}$ & 0.0040 \\
\hline & XLiq1 $* \Delta$ selic & $-0.0322^{*}$ & 0.0176 \\
\hline & $\operatorname{Size}^{*} \Delta$ selic & $0.0037^{* * *}$ & 0.0011 \\
\hline & Size1 $^{*} \Delta$ resdem & $-0.0423 * *$ & 0.0183 \\
\hline & 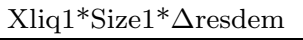 & $0.2008^{* *}$ & 0.0939 \\
\hline & p-val Sargan & 0.178 & \\
\hline & p-val ma1, ma2 & 0.000 & 0.438 \\
\hline & Number of banks, obs. & 247 & 9394 \\
\hline
\end{tabular}

$* / * * / * * *$ denotes significance at $10 / 5 / 1 \%$

(1) It shows the sum of the coefficients that remained significant at $5 \%$ in the final model.

The direct impact of liquidity is positive, implying that more liquid banks also lend more. With respect to the interaction terms, there is a positive coefficient on the interaction between bank size and the selic interest rate. This positive coefficient indicates that smaller banks react strongly to variations in the short-term interest rate. The negative coefficient on the interaction between bank liquidity and the selic interest rate could be interpreted as indicating that a monetary policy tightening relax the liquidity constraints faced by the Brazilian banks. This is 
precisely the result found and the interpretation given by Graminho and Bonomo (2002). We do not prescribe to this interpretation due to two reasons: first, the significance level of the coefficient is relatively high; and, second, and most important, the results reported in table 5 show that this outcome is not robust.

One of the most interesting results we obtain is the negative sign on the interaction between bank size and reserve requirements on demand deposits. In other words, larger banks react more to changes in reserve requirement rates than smaller banks. One possible reason for this finding is associated to the progressive nature of the reserve requirements in Brazil, penalizing larger banks more.

Table 5 reports the results when the reserve requirement rate on demand deposits is replaced by the reserve requirement rate on overall deposits (resdep) as the additional policy instrument.

\section{Table 5}

Impact on free-allocated bank loans - policy instruments: selic interest rate (selic) and reserve requirement rate on overall deposits (resdep)

\begin{tabular}{|c|c|c|c|}
\hline \multicolumn{2}{|c|}{ Variables } & Sum of estimated & Robust \\
\hline \multirow{11}{*}{ in $1^{\text {st }}$ differences } & $\log (\mathrm{L})$ & $0.7202^{* * *}$ & 0.0825 \\
\hline & Selic & -0.0027 & 0.0044 \\
\hline & Resdep & $-0.2927^{* * *}$ & 0.1098 \\
\hline & $\log (y)$ & $0.1611^{* * *}$ & 0.0297 \\
\hline & Infl & $-0.0212^{* * *}$ & 0.0041 \\
\hline & Xliq1 & $0.0150^{* * *}$ & 0.0044 \\
\hline & Size1 $^{*} \Delta$ selic & 0.0002 & 0.0017 \\
\hline & $\operatorname{Size}^{*} \Delta$ resdep & $-0.0807^{* * *}$ & 0.0310 \\
\hline & p-val Sargan & 0.427 & \\
\hline & p-val ma1, ma2 & 0.000 & 0.929 \\
\hline & Number of banks, obs. & 247 & 9381 \\
\hline
\end{tabular}

(1) see the observations in table 4.

With this new policy instrument, both the direct as well as the indirect effects associated to changes in the short-term interest rate cease to be significant. In other words, reserve requirements on overall deposits dominate the policy effects. Thus, the direct impact of this policy instrument on bank loan decisions is now negative and significant. For the average bank, a variation of $1.2 \%$ in the reserve requirement rate on overall deposits, corresponding to a one-standard deviation change in this variable, leads to a long-term contraction of bank loans by $1.26 \%$.

The interaction between bank size and reserve requirements is still negative and highly significant, indicating that this policy instrument affects larger banks more. On the other hand, there is no evidence of significant interactive effects of liquidity with the policy instruments, despite the fact that liquidity has a direct 
positive effect on bank loans. Therefore, the finding of a negative effect for this interaction in table 4 does not seem to be robust. One possible explanation for this lack of significance can be attributed to the fact that positive interest rate shocks have positive impacts on the amount of overall deposits. Such increase in the bank deposits work to smooth the liquidity constraint imposed by the rise in the interest rate.

Thus, there is no evidence that bank loans from less liquid banks react more to interest rate variations. This conclusion is at odds with analogous tests performed for other countries where the effects of the interaction between liquidity and monetary policy indicators are in general very important (Kashyap and Stein, 2000, Ehrmann et al., 2003). The difference in our results can be attributed to the existence of relatively high levels of liquidity in the bank balance sheets due to increased holdings of public bonds in the last years. Such high liquidity levels can cushion the impacts of monetary policy tightenings reducing the effects on bank loans.

\section{Conclusions}

The monetary policy transmission mechanism through bank loan decisions has recently received great attention in the literature. Kashyap and Stein (2000) show evidence to corroborate the existence of this channel for the US and conclude that the effects are mostly driven through small banks with less liquid balance sheets. Similar results are found by Ehrmann et al. (2003) who report evidence that loan supply of less liquid banks are more severely affected by monetary policy changes in several European countries.

The aim of this article was to evaluate the relevance of the bank lending channel in Brazil by looking at micro data from bank balance sheets and by considering other monetary policy instruments in addition to a short-term interest rate. Our results indicate that there is evidence to support the validity of the bank lending channel for Brazil. When the effects of changes in the short-term interest rate and in the reserve requirement rate on overall deposits are jointly tested, one finds that only the last policy instrument has an impact on bank lending decisions. Moreover, this impact is stronger for larger banks.

Graminho and Bonomo (2002) also studied the impact of interest rate variations on lending decisions for a sample of Brazilian banks. They conclude, however, that interest rate rises relax the liquidity constraints on bank balance sheets and therefore that there is no evidence of a bank lending channel for Brazil. Our conclusions differ from theirs mainly due to the inclusion of another policy instrument 
in the form of the reserve requirement rate on overall deposits in our analysis.

One possible extension of the current paper is to evaluate bank level data on the bank loan granting decisions as opposed to our measure. This extension can complement the results of studies with aggregate data for bank loan concession that found evidence in favor of the validity of the bank lending channel in Brazil (Souza Sobrinho and Nakane, 2002).

\section{References}

Arellano, M. \& Bond, S. (1991). Some tests of specification for panel data: Monte Carlo evidence and an application to employment equations. Review of Economic Studies, 58(2):277-297.

Arellano, M., Bond, S., \& Doornik, J. A. (2001). Panel data estimation using DPD for Ox. University of Oxford, mimeo.

Banco Central do Brasil (2000). Juros e Spread Bancário No Brasil - Avaliação de 1 Ano Do Projeto. Departamento de Estudos e Pesquisas - DEPEP.

Banco Central do Brasil (2001). Juros e Spread Bancário No Brasil - Avaliação de 2 Anos Do Projeto. Departamento de Estudos e Pesquisas - DEPEP.

Bernanke, B. \& Blinder, A. (1992). The federal funds rate and the channels of monetary policy transmission. American Economic Review, 82(4):901-921.

Bernanke, B. \& Gertler, M. (1995). Inside the black box: The credit channel of monetary policy transmission. Journal of Economic Perspectives, 9(4):27-48.

Bogdanski, J., Tombini, A. A., \& Werlang, S. R. C. (2000). Implementing inflation targeting in Brazil. Banco Central do Brasil, Working Paper n. 1.

Brissimis, S. N., Kamberoglou, N. C., \& Simigiannis, G. T. (2003). Is there a bank lending channel of monetary policy in Greece? Evidence from bank level data. In Angeloni, I., Kashyap, A., \& Mojon, B., editors, Monetary Transmission in the Euro Area: A Study by the Eurosystem Monetary Transmission Network, pages 309-322. Cambridge University Press, Cambridge.

Cukierman, A. \& Hercowitz, Z. (1989). Oligopolistic financial intermediation, inflation and the interest rate spread. Foerder Institute for Economic Research, Tel-Aviv University, Working Paper n. 17-89. 
De Gregorio, J. \& Sturzenegger, F. (1997). Financial markets and inflation under imperfect information. Journal of Development Economics, 54(1):149-168.

Ehrmann, M., Gambacorta, L., Martínez-Pagés, J., Sevestre, P., \& Worms, A. (2003). Financial systems and the role of bank in monetary transmission in the Euro area. In Angeloni, I., Kashyap, A., \& Mojon, B., editors, Monetary Transmission in the Euro Area: A Study by the Eurosystem Monetary Transmission Network, pages 235-269. Cambridge University Press, Cambridge.

Farinha, L. \& Robalo Marques, C. (2003). The bank lending channel of monetary policy: identification and estimation using Portuguese micro bank data. In Angeloni, I., Kashyap, A., \& Mojon, B., editors, Monetary Transmission in the Euro Area: A Study by the Eurosystem Monetary Transmission Network, pages 359-371. Cambridge University Press, Cambridge.

Gambacorta, L. (2003). The Italian banking system and monetary policy transmission: Evidence from bank-level data. In Angeloni, I., Kashyap, A., \& Mojon, B., editors, Monetary Transmission in the Euro Area: A Study by the Eurosystem Monetary Transmission Network, pages 323-334. Cambridge University Press, Cambridge.

Gertler, M. \& Gilchrist, S. (1993). The role of credit market imperfections in the monetary transmission mechanism: Arguments and evidence. Scandinavian Journal of Economics, 95(1):43-64.

Graminho, F. M. \& Bonomo, M. A. (2002). O canal de empréstimos bancários no Brasil: Uma evidência microeconômica. Anais do XXX Encontro Nacional de Economia da ANPEC (CD-ROM).

Hernando, I. \& Martínez-Pagés, J. (2003). Is there a bank lending channel of monetary policy in Spain? In Angeloni, I., Kashyap, A., \& Mojon, B., editors, Monetary Transmission in the Euro Area: A Study by the Eurosystem Monetary Transmission Network, pages 284-296. Cambridge University Press, Cambridge.

Huybens, E. \& Smith, B. D. (1999). Inflation, financial markets and long-run real activity. Journal of Monetary Economics, 43(2):283-315.

Kashyap, A. K. \& Stein, J. C. (1994). Monetary policy and bank lending. In Mankiw, N. G., editor, Monetary Policy, pages 221-256. University of Chicago Press, Chicago. 
Kashyap, A. K. \& Stein, J. C. (1995). The impact of monetary policy on bank balance sheets. Carnegie-Rochester Conference Series on Public Policy, 42:151195.

Kashyap, A. K. \& Stein, J. C. (2000). What do a million observations on banks say about the transmission of monetary policy? American Economic Review, 90(3):407-428.

Kashyap, A. K., Stein, J. C., \& Wilcox, D. W. (1993). Monetary policy and credit conditions: Evidence from the composition of external finance. American Economic Review, 83(1):78-98.

Kaufmann, S. (2003). The cross-sectional and the time dimension of the banklending channel: The Austrian case. In Angeloni, I., Kashyap, A., \& Mojon, B., editors, Monetary Transmission in the Euro Area: A Study by the Eurosystem Monetary Transmission Network, pages 347-358. Cambridge University Press, Cambridge.

Melo, F. \& Teles, W. (1998). O spread bancário e o compulsório. Nota Técnica DEPEC-97/02, Boletim do Banco Central do Brasil.

Nakane, M. I. \& Takeda, T. (2002). Impactos da política monetária nos balanços bancários - uma análise VAR. In Economia Bancária e Crédito - Avaliação de 3 Anos Do Projeto Juros e Spread. Departamento de Estudos e Pesquisas DEPEP, Banco Central do Brasil.

Oliner, S. \& Rudebusch, G. (1996). Is there a broad credit channel for monetary policy? Federal Reserve Board of San Francisco Economic Review, 3(13).

Peek, J. \& Rosengren, E. S. (1995). Bank lending and the transmission of monetary policy. In Peek, J. \& Rosengren, E. S., editors, Is Bank Lending Important for the Transmission of Monetary Policy?, pages 39, 47-68. Federal Reserve Bank of Boston Conference Series.

Souza Sobrinho, N. F. \& Nakane, M. I. (2002). Uma avaliação do canal do crédito no Brasil. Anais do XXX Encontro Nacional de Economia da ANPEC (CD$\mathrm{ROM})$.

Worms, A. (2003). The reaction of bank lending to monetary policy measures in Germany. In Angeloni, I., Kashyap, A., \& Mojon, B., editors, Monetary Transmission in the Euro Area: A Study by the Eurosystem Monetary Transmission Network, pages 270-283. Cambridge University Press, Cambridge. 